\title{
IAMJ
}

INTERNATIONAL

AYURVEDIC

MEDICAL JOURNAL

Case Report

ISSN: 2320-5091

Impact Factor: 6.719

\section{AYURVEDIC PROTOCOL FOR THE MANAGEMENT OF WILSON'S DISEASE - A CASE REPORT}

\author{
Priya Pantel $^{1 *}$, Swati Nagpal ${ }^{2}$ \\ ${ }^{1}$ PG Scholar, Department of Kayachikitsa, Pt. Khushilal Sharma Govt. (Auto) College \& Institute, Bhopal (M.P.) \\ 462003, India \\ ${ }^{2}$ Reader, Department of Kayachikitsa, Pt. Khushilal Sharma Govt. (Auto) College \& Institute, Bhopal (M.P.) \\ 462003, India
}

Corresponding Author: dr.priyapantel11@gmail.com

\section{https://doi.org/10.46607/iamj4509072021}

(Published Online: July 2021)

Open Access

(C) International Ayurvedic Medical Journal, India 2021

Article Received: 21/06//2021 - Peer Reviewed: 25/06/2021 - Accepted for Publication: 27/06/2021

\section{Check for updates}

\begin{abstract}
Wilson's disease (hepatolenticular degeneration) is a rare important autosomal recessive disorder caused by dysfunction of the copper transporter ATP7B, which leads to snagging in copper transport by the hepatic lysosomes resulted in the deposition of copper in the brain, liver, kidney, or skeletal system. The symptoms are jaundice, Kayser-Fleischer rings, dysarthria, ataxia, and muscle spasticity etc. Current therapeutic modalities for the management of Wilson's disease include zinc, trientine, penicillamine etc. In Ayurvedic classics there is no exact correlation is available for this disease entity that exactly matches the feature of Wilson disease, but it can be correlated with Vatavyadhi under the Sahaja Vyadhi (Heredity) or Janamjata Vyadhi (congenital). The treatment ${ }^{1}$ mentioned for Vatavyadhi is Snehana (oleation), Mrudu Swedana (mild sedation), Anuvasana Basti (oil enema) and Niruha Basti (Decoction Enema). Material and methods: An 18-year-old male patient with Wilson disease complained of short stepping gait, persistent constipation, tremors, changed speech, generalised stiffness, and frequent eye blinking. S. Ceruloplasmin was found to be $18.33 \mathrm{mg} / \mathrm{dL}$ (usually $20 \mathrm{mg} / \mathrm{dl}$ to $40 \mathrm{mg} / \mathrm{dl}$ ), S. copper was found to be within normal limits, and a slit lamp assay for the KF ring was negative. Ayurvedic therapy was used in conjunction with oral medicine throughout the treatment. Results: Clinical observations revealed that the patient's earlier symptoms had significantly improved, and he was able to carry out his usual activities with ease. Duration of treatment:
\end{abstract}


three months. Conclusion: From the case study it can be concluded that the Ayurvedic medications and Panchkarma therapy in such patients may help in providing supportive care and improving the quality of life.

Keywords: Vatavyadhi, Shaman Chikitsa, Bastikarma, Wilson's disease.

\section{INTRODUCTION}

Wilson's disease is an inborn error of metabolism owing to toxic accumulation of copper in vital areas including the liver, Brain, Cornea and other tissues. All siblings of the patient should be examined to detect the possibility of asymptomatic $\mathrm{WD}^{2}$. Wilson's disease is caused by the inheritance of two defective copies of the ATP7B gene from the parent gene. WD might manifest as hepatic, neurologic, or mental issues in both men and women. A build-up of copper in the central nervous system causes neurological symptoms such as tiredness, anorexia, and jaundice, according to Kayser-Fleischer syndrome, rings, edema in legs, ascites, dysarthria, dysphagia, ataxia, dyskinesia and muscle spasticity. It is prevalence ${ }^{3,4}$ of around 0.5 cases per 100,000 inhabitants.

\section{Diagnostic test:}

Order a ceruloplasmin level if you are suspicious of WD. It will be less than $20 \mathrm{mg} / \mathrm{dl}$ (typically $20 \mathrm{mg} / \mathrm{dl}$ to $40 \mathrm{mg} / \mathrm{dl}$ ) and urine copper levels will be higher than $100 \mathrm{mcg} / \mathrm{dl}$, both of which are considered diagnostic criteria for WD. The existence of Kayser-Fleischer ${ }^{5,6}$ rings may generally be detected with a slit-lamp examination of the eyes, but the absence of Kayser Fleischer rings does not exclude the diagnosis of $\mathrm{WD}$, even in patients with predominantly neurological disease (Class I, Level B). It may be absent in $5 \%$ of cases. A liver biopsy is also done in certain individuals for copper analysis to confirm the diagnosis of Wilson disease.

There are two types of treatment: (i) induction therapy and (ii) maintenance therapy. The goal of induction treatment is to lower copper levels below the hazardous threshold. This stage generally lasts between 4 and 6 months. Chelation treatment with D- penicillamine or trientine is commonly used. The goal of maintenance treatment is to keep a slightly negative copper balance to avoid copper buildup and toxicity. Zinc can be used for this therapy because of its reduced cost and safety profile4. Pharmacotherapy must be continued throughout one's life. Due to the ineffectiveness of anti-copper medicines, liver transplantation is the only effective therapy for severe liver disease.

There is no specific definition of the disease entity in Ayurveda that is identical to WD, however certain symptoms are comparable to Vatavyadhi Lakshnas. When vitiated doshas deprive Beeja (ovum or sperm) and Beejabhaga (chromosome/gene) during garbhakala. Garbh's organ will get malformed. (Ch.Sha.30/4) As a result, Beeja-doshjanya Vikara, Sahajavyadhi, and Vatavyadhi may be linked to Wilson's illness.

\section{Case Report}

The present case study was of an a18-year-old male patient with complaints of short stepping gait, chronic constipation, tremors, altered speech, generalized stiffness and frequent blinking of eyes. The associated complaints were pain in multiple joints, Chronic constipation-1times/3days for 2 years, mood swings and poor appetite. The patient was said to be healthy 5 years back and then Symptoms were gradually developed and progressive. In 2015 patient diagnosed with Wilson disease. immediately he started allopathic treatment (Tab. zinc \& Tab. Epilan twice a day etc.) but parents didn't observe any improvement. So, treatment was stopped, and the patient was brought to $\mathrm{KC}$. OPD (on dated 5/01/2021) at Ptkls ayurvedic Hospital, Bhopal with the above complaints.

\section{History}

Gross motor and fine motor skills were normal, and the last social milestone was also typical for age. Language skills were likewise normal, and there was no history of Delayed Milestones as evidenced by verbal evidence from parents.

\section{Birth History}

Birth history revealed that the child was born as a premature baby with an average birth of $2.6 \mathrm{~kg}$ through 
normal Vaginal delivery, cried soon after birth and no NICU stay.

\section{Immunization history}

All the essential vaccines were given according to schedule.

Table 1: General examination

\begin{tabular}{|l|l|l|l|l|}
\hline Pulse & BP & RR & Temp. & Body wt \\
\hline $72 / \mathrm{min}$ & $120 / 80 \mathrm{mmHg}$ & $18 / \mathrm{min}$ & $98.6 \mathrm{~F}$ & $45 \mathrm{~kg}$ \\
\hline
\end{tabular}

Systemic examination-All vitals were normal.

Diagnosis: Wilson's Disease as this case had one of the hallmarks of WD i.e Bilateral Kayser - Fleischer Corneal rings (KF Ring), then followed by the investigation of Urine Copper in 24 hrs. - 448 microgram/24 hours which was increased and the diagnostical CT brain impression was confirmed with Wilson Disease which concluded from a differential diagnosis like
Chronic liver disease, Parkinson's disease, multiple sclerosis.

Investigations: CT scan of Brain (22/10/20) shows the symmetrical area of altered signal intensity showing blooming of $\mathrm{GrE}$ involving bilateral basal ganglia and dentate nucleus. Hyperostosis frontalis interna.

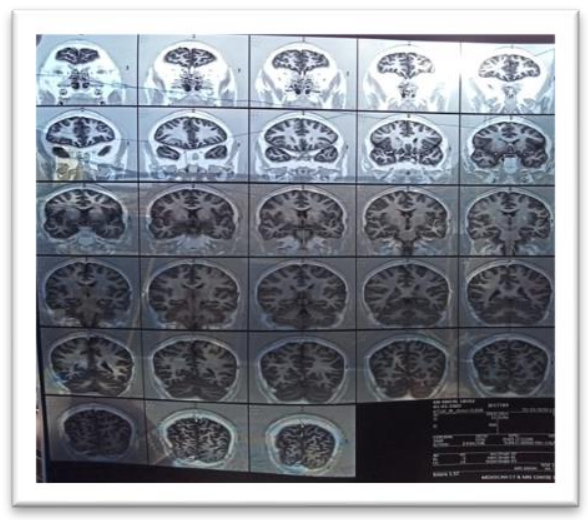

Figure 1- CT scan of Brain

\section{Treatment Protocol}

Table 2: Oral Medication

\begin{tabular}{|l|l|l|l|l|}
\hline Sr.N. & Drug & Dose & Anupan & Duration \\
\hline 1 & Chitradi vati & $2 *$ TDS & - & 15 days \\
\hline 2 & Laghumalini Basantrasa & $125 \mathrm{mg} * \mathrm{BD}$ & Water & 30days \\
\hline 3 & Swadishta virechana churna & $5 \mathrm{gm} * \mathrm{HS}$ & Lukewarm water & 60days \\
\hline 4 & Agnitundi vati ${ }^{7}$ & $1 * \mathrm{BD}$ & Water & 45days \\
\hline 5. & Panchkola Phanta & $20 * \mathrm{ml} \mathrm{OD}$ & - & 45 days
\end{tabular}

Table 3: Panchakarma Therapy

\begin{tabular}{|l|l|l|l|}
\hline S.N. & Karma & Dravya & Kala \\
\hline 1 & Matra Basti & Sahcharadi Tail & 45 days \\
\hline 2 & Sarwang patra pinda swedana & Mahanarayan Tail & $60 d a y s$ \\
\hline 3 & Shirodhara & Jatamansi Kwath & $90 d a y s$ \\
\hline
\end{tabular}

\section{Observations \& Results}

On clinical observations, the patient got relief in joint pain, Chronic constipation, blinking of eyes and anorexia in their 15 days of treatment. So, the treatment plan had been modified for better management then Matra Basti was Introduced. After 90 days of treatment, there was a significant improvement in the previous condition.

\section{DISCUSSION}

Swadishta virechan churna is used for Mridu Virechana for the removal of Pitta Dosha and constipation. Initially, to treat Agnimandya, Chitradi Vati \& Panchakola Phanta was given for Deepana Pachana action. Above Formulation, combinedly targeted digestive system and prevent adhesion of the channels and patient got relief from constipation.

Because Snehana (Oleation), Swedana (Sudation), and Basti (Oil Enema) have been cited as the best treatments for Vataja disease, Patra Pinda Swedana was 
planned together with Matra Basti (Sahcharadi Taila). Stabdhata (stiffness) was caused by Vata's Sheeta (cold) Ruksha (dry) properties, whereas Bala's Snigdha (unctuous) and Bruhmana (nourishing) characteristics, as well as Taila's Ushna Guna, served to calm Vata Dosha and therefore relieve polyarticular pain and stiffness. Matra Basti opted with the drug that was having Vatashamak effect, so the patient got much relief in such complaints i.e. frequent blinking of eyes, tremors. Due to lipid-soluble content present in Panchendriyavivardhna Taila, it gets absorbed by the nasal olfactory cilia and stimulates the olfactory nerves which relate to the higher centers of the brain. Medhya and Vata-Kapha Shamaka properties of Panchendriyavivardhna Taila may give a synergistic action helping to correct the mental and intellectual functions.

Shirodhara is a classical Ayurvedic procedure in which medicated Dravya (Jatamansi) steadily dripping on the centre of the forehead of the patient. It induces a relaxed state of awareness which results in a dynamic psychosomatic balance ${ }^{8}$. As evident from the results of the present case study, the selected treatment modality helped in reducing the above-mentioned complaints.

Repeated sittings of intervention and advanced Panchakarma procedures may be necessary to completely modify the pathogenesis and cure the condition completely which was not done in the present case study as because of a covid pandemic the patient further did not come for the next treatment plan.

\section{CONCLUSION}

The present case study was an exploration of a unique and rare case of Wilson's disease diagnosed as Vatavyadhi under the Sahaja Vyadhi(heredity) or Janamjata Vyadhi (congenital) with specific Vatahara Chikitsa. Ayurvedic approach and diet modification have shown good results in reducing symptoms. From this case study, it could be concluded that WD mab be correlated with Vatavyadhi and above treatment protocol gives much better results in future. No such adverse effect observed during treatment in this patient.

\section{REFERENCES}

1. Shashtri kashinath, Chaturvedi Gorakhnath edited Charak Samhita of Agnivesha, revised by Charak and Dridbala, part 2 Chaukhamba Bharti Academy, Varanasi, reprint 2017, verse 17; page no.791-792.

2. O P Ghai. Ghai Essential Pediatrics. 9th ed., New Delhi: CBS Publishers \& Distributors; 2019, Diseases of Gastrointestinal System \& Liver, Chapter no.12. p.322.

3. Scheinberg IH, Sternlieb I. Wilson's disease. In: Smith JL, editor. Major problems in internal medicine. Philadelphia: WB Saunders; 1984. p. 25e35.

4. Ala A, Walker AP, Ashkan K, Dooley JS, Schilsky ML. Wilson's disease. Lancet. 2007; 369:397-408. [PubMed] [Google Scholar]

5. Roberts EA, Schilsky ML. American Association for the study of liver diseases (AASLD) diagnosis and treatment of Wilson's disease: an update. Hepatology 2008;47(6):2089e111

6. Demirkiran M, Jankovic J, Lewis RA, Cox DW. Neurologic presentation of Wilson disease without KayserFleischer rings. Neurology 1996;46: 1040-1043.

7. Govinda D. Bhaisajya Ratnavali, Mandagni (Dyspepsia), Chapter.10, Verse 93- 94, Vol.1,

8. Reprint ed., Varanasi: Chaukhambha Subharati Prakashan; 2007, p..649.

9. Uebaba K, Xu FH, Ogawa H, Tatsuse T, Wang BH, Hisajima T, et al. Psychoneuroimmunologic effects of Ayurvedic oil-dripping treatment. J Altern Complement Med. 2008; 14:1189-98. [PubMed] [Google $\underline{\text { Scholar }}$

\section{Source of Support: Nil Conflict of Interest: None Declared}

How to cite this URL: Priya Pantel \& Swati Nagpal: Ayurvedic Protocol For The Management Of Wilson's Disease - A Case Report. International Ayurvedic Medical Journal \{online\} $2021 \quad$ cited July 2021\} Available from: http://www.iamj.in/posts/images/upload/1593_1596.pdf 